\title{
Studies on Time Duration of Life Stages of Chrysomya megacephala and Chrysomya rufifacies (Diptera: Calliphoridae) during Different Seasons
}

Shabnamnaz Siddiki ${ }^{*}$ and Zambare SP

Department of Zoology, Dr. Bababsheb Ambedkar Marathwada University, Aurangabad, (M.S.) India

*Corresponding author: Shabnamnaz Siddiki, Dr Babasaheb Ambedkar Marathwada University, Near Soneri Mahal Jaisingpuara, Aurangabad, Maharashtra 431004, India, Tel: +919730391091; E-mail: shabnam.naz85@gmail.com

Received date: April 08, 2017; Accepted date: May 24, 2017; Published date: May 29, 2017

Copyright: () 2017 Siddiki S, et al. This is an open-access article distributed under the terms of the Creative Commons Attribution License, which permits unrestricted use, distribution, and reproduction in any medium, provided the original author and source are credited.

\begin{abstract}
Accurate estimation of post mortem interval (PMI) can be crucial to the successful investigation of suspicious death. The forensic indicator blowflies are essential for accuracy in estimation of PMI. The Calliphoridae species Chrysomya megacephala and Chrysomya rufifacies were reared in laboratory condition for studying their time duration of different stages under the fluctuating temperature in three different seasons (i.e. rainy season, winter season and summer season).
\end{abstract}

In laboratory, at the fluctuating temperature during rainy season, winter season and summer season, Chrysomya megacephala took 237 hours 47 minutes, 263 hours 51 minutes and 211 hours 13 minutes respectively. Whereas the Chrysomya rufifacies took 239 hours 14 minutes, 286 hours 02 minutes and 216 hours 26 minutes during rainy season, winter season and summer season respectively.

This study shows that forensic investigators will have to take each of these variables into consideration from the development of insects in order to give a more accurate estimate of PMI.

Keywords: Forensic entomology; Postmortem interval; Seasonal life cycle duration; Fluctuating temperature

\section{Introduction}

The family Calliphoridae includes blow-flies (also frequently spelled green bottle, blue bottle or carrion flies), the well-known scavenger insects belonging to the order Diptera. Blowfly is usually the first insects to come in contact with dead body remains [1]. Worldwide there are 1100 species in the neotropics [2], but very numerous species in Africa and Southern Europe.

Both male and female adult Calliphoridae ranges from 6 to $14 \mathrm{~mm}$ in length. The adult size depends on species and food availability to the larval stages. The majority of these species are metallic in appearance with colour ranging from brilliant green or blue to bronze or shiny black [3]. In some species, a covering of fine hairs, powder or dust masks the bright metallic coloration of fly epicuticle. Adults are characterized by a three segmented antenna located between and anterior to the pair of compound eyes. This antenna has a hair or arista on the last segment which is plumose or hairy throughout its length [4].

The typical habitat of blowflies are temperate to tropical areas that provide a layer of loose, damp soil and litter where larvae may thrive and pupate [5]. Adult blowflies are occasionally pollinator, being attracted to flowers and strong odour resembling rotting meat such as American pawpaw and dead horse arum. The larvae of Calliphoridae feeds on remains or other decaying matter [6]. Most species of blowflies studied thus far are anautogenous; female requires a substantial amount of protein to develop mature eggs within her ovaries (about $800 \mu \mathrm{g}$ per pair of ovaries in Phormia regina). The female visit remains for both protein and egg lay. Blowfly eggs are about $1.5 \mathrm{~mm} \times 0.4 \mathrm{~mm}$, white or yellowish, looks like rice balls when laid. While the female blowfly typically lays 150 to 200 eggs per batch, she is usually iteroparous, laying around 2000 eggs during her course of life. The sex ratio of blowfly eggs is usually 50:50 [7], but in one interesting exception currently documented literature, female from two species of Chrysomya ( $C$. rufifaces and $C$. albiceps) are either arrhenogenic (laying only male offsprings) or thelygenic (laying only female offsprings). Blowflies are usually the first insects to come in contact with carrion because they have an ability to smell dead animal matter from upto 10 miles $(16 \mathrm{Km})$ [8]. Upon reaching carrion, female deposit eggs onto the body. Since development is highly predictable if the ambient temperature is known, blowfly are considered a valuable tools in forensic science to determine post mortem interval (PMI). Traditional estimation of time since death are generally unreliable after 72 hours and often entomologist are the only officials capable of generating an actuating approximate time interval.

This research work was taken up in order to study the time duration of different stages of Chrysomya megacephala and Chrysomya rufifaces during different season so as to prepare the baseline data that will help the forensic experts to find correct PMI in Indian conditions.

\section{Materials and Methods}

The present research work was carried out at research laboratory. The species Chrysomya megacephala and Chrysomya rufifacies flies were used as the biomaterials and different appliances and tools were used. 


\section{Collecting and rearing of blowflies}

The species Chrysomya megacephala and Chrysomya rufifacies flies were collected from carcass in Latur district, Maharashtra, India.

The fresh liver sample was purchased from the local slaughter house. Partially putrefied liver and meat was exposed in the sampling site and within few minutes the flies were attracted. The flies were collected by the insect net and after identification they were released in the insect rearing cages. Honey solution (water and honey) soaked in tissue paper was kept in petridish and fresh sliced liver meat of cattle was provided daily in separate petridishes in the rearing cages. After few days the mated adult female started laying eggs on sliced liver meat. The eggs were collected with the help of fine brush directly after laying. The blowflies laid eggs on the sliced liver meat which was later on reared in rainy, winter and summer seasons at laboratory condition. The plastic jar was taken for rearing the instars of blowfly larvae. The liver meat was then placed into $6 \mathrm{~cm}$ deeper jar covered with fine mesh to prevent the entry of parasitoids. The three experiments were conducted at the same time. Three groups of 50 larvae separately transferred into three plastic jars and fed them fresh liver meat daily till pupation. Observation was taken on hourly basis. The maggots were observed and collected with the help of forceps and preserved in small bottle throughout their developmental stages at different time duration. As the third instar larva finished feeding and reach wandering phase, they left the food and travel to the soil for pupation. After few days the adult fly emerged out from the pupa. The total time taken by each stages of Chrysomya megacephala and Chrysomya rufifacies life cycle during different seasons was recorded. The temperature and humidity were recorded daily with the help of Hygrothermometer clock. The experiment was repeated three times seasonally.

\section{Statistical Analysis}

Statistical analysis was performed using the excel sheet, data were analyzed by using two way analysis of variances (ANOVA) and significance level at $\mathrm{P} \leq 0.05$.

\section{Observations and Results}

In present research work it is observe that the blowflies reaches from $\mathrm{I}^{\text {st }}$ instar larvae to $\mathrm{II}^{\text {nd }}$ and then III ${ }^{\text {rd }}$ instar larvae after their moulting completion. The time duration of different stages are of Chrysomya megacephala and Chrysomya rufifacies during different seasons are as follows

\section{Chrysomya megacephala}

\section{Rainy season}

The average temperature and humidity during the experiment was $24.1^{\circ} \mathrm{C}$ and $49.6 \%$ respectively. Table 1 showed the time duration of different stages of Chrysomya megacephala during rainy season. Result revealed that the eggs took 18 hours 37 minutes for incubation. After incubation there are three stages of larval instars (i.e. $\mathrm{I}^{\text {st }}$ instar, $\mathrm{II}^{\text {nd }}$ instar and III ${ }^{\text {rd }}$ instar). The duration of I ${ }^{\text {st }}$ instar larva took 25 hours 45 minutes and post mortem interval (PMI) duration persisted 44 hours 22 minutes since egg laid. The II ${ }^{\text {nd }}$ instar larva took 26 hours 35 minutes to reach third instar larva and PMI duration was 70 hours 57 minutes. The IIIrd instar larva persisted 29 hours while PMI duration since egg laid upto III ${ }^{\text {rd }}$ instar was 99 hours 57 minutes. The pre-pupal stage took 22 hours 40 minutes and PMI duration was 122 hours 37 minutes. The time taken by pupal stages upto adult fly emerged was 115 hours 10 minutes while the total duration took by Chrysomya megacephala in rainy season was 237 hours 47 minutes (Table 1).

\begin{tabular}{|l|l|l|l|}
\hline \multicolumn{2}{|l|}{ Life cycle stages } & Duration (H:MM) & PMI (H:MM) \\
\hline \multirow{2}{|l|}{ Eggs } & Ist instar & $18: 37$ & \\
\hline \multirow{3}{*}{ Larva } & II ${ }^{\text {nd }}$ instar & $25: 45$ & $44: 22$ \\
\cline { 2 - 4 } & IIIrd instar & $26: 35$ & $70: 57$ \\
\hline Pre-pupa & $29: 00$ & $99: 57$ \\
\hline Pupa & $22: 40$ & $122: 37$ \\
\hline Total duration & $115: 10$ & $237: 47$ \\
\hline
\end{tabular}

Table 1: Time duration of different stages of Chrysomya megacephala during rainy season.

\section{Winter season}

The average temperature and humidity during the experiment was $22.7^{\circ} \mathrm{C}$ and $35.8 \%$ repectively. Table 2 shows the time duration of different stages of Chrysomya megacephala during winter season. The result showed the eggs persisted 20 hours 36 minutes. After hatching eggs the It $^{\text {st }}$ instar larva took 26 hours 30 minutes to become II $^{\text {nd }}$ instar larva stage. The PMI duration since egg laid was 47 hours 06 minutes. The IInd instar larva took 28 hours 30 minutes to reach third instar larva and the PMI duration was 75 hours 36 minutes. The III ${ }^{\text {rd }}$ instar larva took 48 hours and PMI duration was 123 hours 36 minutes. The pre-pupal stage persisted 21 hours 50 minutes to reach pupal stage while PMI duration was 145 hours 26 minutes. The pupal stage took 118 hours 25 minutes to become adult fly emerged. The total duration of whole life cycle of Chrysomya megacephala during winter season was 263 hours 51 minutes (Table 2).

\begin{tabular}{|c|c|c|c|}
\hline \multicolumn{2}{|c|}{ Life stages } & Duration (H:MM) & PMI (H:MM) \\
\hline \multicolumn{2}{|l|}{ Eggs } & $20: 36$ & \\
\hline \multirow{3}{*}{ Larva } & $\mathrm{I}^{\text {st }}$ instar & $26: 30$ & $47: 00$ \\
\hline & II ${ }^{\text {nd }}$ instar & $28: 30$ & $75: 36$ \\
\hline & III ${ }^{\text {rd }}$ instar & 48:00 & $123: 36$ \\
\hline \multicolumn{2}{|c|}{ Pre-pupa } & $21: 50$ & $145: 26$ \\
\hline \multicolumn{2}{|l|}{ Pupa } & $118: 25$ & $263: 51$ \\
\hline \multicolumn{2}{|c|}{ Total duration } & \multicolumn{2}{|l|}{$263: 51$} \\
\hline
\end{tabular}

Table 2: Time duration of different stages of Chrysomya megacephala during winter season.

\section{Summer season}

The average temperature and humidity during the experiment was $32.5^{\circ} \mathrm{C}$ and $21.5 \%$ respectively. Table 3 shows the time duration of different stages of Chrysomya megacephala during summer season. The result showed the eggs persisted 18 hours 08 minutes. After hatching eggs the $\mathrm{I}^{\text {st }}$ instar larva took 26 hours 05 minutes to become 
Citation: Siddiki S, Zambare SP (2017) Studies on Time Duration of Life Stages of Chrysomya megacephala and Chrysomya rufifacies (Diptera: Calliphoridae) during Different Seasons. J Forensic Res 8: 379. doi:10.4172/2157-7145.1000379

Page 3 of 5

II ${ }^{\text {nd }}$ instar larva stage. The PMI duration since egg laid was 44 hours 13 minutes. The II $^{\text {nd }}$ instar larva took 26 hours 45 minutes to reach third instar larva and the PMI duration was 70 hours 58 minutes. The III ${ }^{\text {rd }}$ instar larva took 27 hours 05 minutes and PMI duration was 98 hours 03 minutes. The pre-pupal stage persisted 20 hours 10 minutes to reach pupal stage while PMI duration was 118 hours 13 minutes. The pupal stage took 93 hours to become adult fly emerged. The total duration of whole life cycle of Chrysomya megacephala during summer season was 211 hours 13 minutes (Table 3 ).

\begin{tabular}{|l|l|l|l|}
\hline \multicolumn{2}{|l|}{ Life stages } & Duration (H:MM) & PMI (H:MM) \\
\hline \multirow{2}{*}{ Eggs } & Ist instar & $18: 08$ & \\
\hline \multirow{3}{*}{ Larva } & II $^{\text {nd }}$ instar & $26: 05$ & $44: 13$ \\
\cline { 2 - 4 } & IIIrd instar & $26: 45$ & $70: 58$ \\
\hline Pre-pupa & $27: 05$ & $98: 03$ \\
\hline Pupa & $20: 10$ & $118: 13$ \\
\hline Total duration & $93: 00$ & $211: 13$ \\
\hline
\end{tabular}

Table 3: Time duration of different stages of Chrysomya megacephala during summer season.

\section{Chrysomya rufifacies}

\section{Rainy season}

The average temperature and humidity during the experiment was $24^{\circ} \mathrm{C}$ and $42.1 \%$ respectively. Table 4 showed the time duration of different stages of Chrysomya rufifacies during rainy season. Result revealed that the eggs took 22 hours 38 minutes for incubation. After incubation there are three stages of larval instars (i.e. $\mathrm{I}^{\text {st }}$ instar, II ${ }^{\text {nd }}$ instar and III ${ }^{\text {rd }}$ instar). The duration of $\mathrm{I}^{\text {st }}$ instar larva took 25 hours 06 minutes and post mortem interval (PMI) duration persisted 47 hours 44 minutes since egg laid.

\begin{tabular}{|l|l|l|l|}
\hline \multicolumn{2}{|l|}{ Life stages } & Duration (H:MM) & PMI (H:MM) \\
\hline \multicolumn{2}{|l|}{ Eggs } & $22: 38$ & \\
\hline \multirow{2}{*}{ Larva } & Ist instar $^{\text {IIIId } \text { instar }}$ & $25: 06$ & $47: 44$ \\
\cline { 2 - 4 } & III instar & $27: 35$ & $75: 19$ \\
\hline Pre-pupa & $51: 05$ & $126: 24$ \\
\hline Pupa & $41: 50$ & $168: 14$ \\
\hline \multirow{2}{*}{ Total duration } & $71: 00$ & $239: 14$ \\
\hline
\end{tabular}

Table 4: Time duration of different stages of Chrysomya rufifacies during rainy season.

The IInd instar larva took 27 hours 35 minutes to reach third instar larva and PMI duration was 75 hours 19 minutes. The IIIrd instar larva persisted 51 hours 05 minutes while PMI duration since egg laid upto IIIrd instar was 126 hours 24 minutes. The pre-pupal stage took 41 hours 50 minutes and PMI duration was 168 hours 14 minutes. The time taken by pupal stages upto adult fly emerged was 71 hours while the total duration took by Chrysomya rufifacies in rainy season was 239 hours 14 minutes (Table 4 ).

\section{Winter season}

The average temperature and humidity during the experiment was $25^{\circ} \mathrm{C}$ and $46.8 \%$ respectively. Table 5 shows the time duration of different stages of Chrysomya rufifacies during winter season. The result showed that the eggs persisted 19 hours 02 minutes. After hatching eggs the $\mathrm{I}^{\text {st }}$ instar larva took 46 hours 15 minutes to become II ${ }^{\text {nd }}$ instar larva stage. The PMI duration since egg laid was 65 hours 17 minutes. The II ${ }^{\text {nd }}$ instar larva took 28 hours 25 minutes to reach third instar larva and the PMI duration was 93 hours 45 minutes. The IIIrd instar larva took 50 hours 05 minutes and PMI duration was 143 hours 47 minutes. The pre-pupal stage persisted 24 hours 35 minutes to reach pupal stage while PMI duration was 168 hours 22 minutes. The pupal stage took 117 hours 40 minutes to emerge adult fly. The total duration of whole life cycle of Chrysomya rufifacies during winter season was 286 hours 02 minutes (Table 5).

\begin{tabular}{|l|l|l|l|}
\hline \multicolumn{2}{|l|}{ Life stages } & Duration (H:MM) & PMI (H:MM) \\
\hline \multirow{2}{|l|}{ Eggs } & $19: 02$ & \\
\hline \multirow{3}{*}{ Larva } & It $^{\text {instar }}$ & $46: 15$ & $65: 17$ \\
\cline { 2 - 4 } & II $^{\text {nd }}$ instar & $28: 25$ & $93: 45$ \\
\cline { 2 - 4 } & IIId instar & $50: 05$ & $143: 47$ \\
\hline Pre-pupa & $24: 35$ & $168: 22$ \\
\hline Pupa & $117: 40$ & $286: 02$ \\
\hline \multicolumn{2}{|l|}{ Total duration } & $286: 02$ & \\
\hline
\end{tabular}

Table 5: Time duration of different stages of Chrysomya rufifacies during winter season.

\section{Summer season}

The average temperature and humidity during the experiment was $32^{\circ} \mathrm{C}$ and $22.07 \%$ respectively. Table 6 shows the time duration of different stages of Chrysomya rufifacie during summer season. The result showed that the eggs persisted 19 hours 21 minutes.

\begin{tabular}{|l|l|l|l|}
\hline \multicolumn{2}{|l|}{ Life stages } & Duration (H:MM) & PMI (H:MM) \\
\hline \multirow{2}{|l|}{ Eggs } & $19: 21$ & \\
\hline \multirow{3}{*}{ Larva } & Ist instar $^{*}$ & $25: 45$ & $45: 06$ \\
\cline { 2 - 4 } & III $^{\text {II }}$ instar & $28: 00$ & $73: 06$ \\
\cline { 2 - 4 } Pre-pupa & $48: 40$ & $121: 46$ \\
\hline Pupa & $20: 10$ & $141: 56$ \\
\hline Total duration & $74: 30$ & $216: 26$ \\
\hline
\end{tabular}

Table 6: Time duration of different stages of Chrysomya rufifacies during summer season. 
After hatching eggs the $\mathrm{I}^{\text {st }}$ instar larva took 25 hours 45 minutes to became II $^{\text {nd }}$ instar larva stage. The PMI duration since egg laid was 45 hours 06 minutes. The IInd instar larva took 28 hours to reach third instar larva and the PMI duration was 73 hours 06 minutes. The III ${ }^{\mathrm{rd}}$ instar larva took 48 hours 40 minutes and PMI duration was 121 hours 46 minutes. The pre-pupal stage persisted 20 hours 10 minutes to reach pupal stage while PMI duration was 141 hours 56 minutes. The pupal stage took 74 hours 30 minutes to become adult fly emerged. The total duration of whole life cycle of Chrysomya rufifacies during summer season was 216 hours 26 minutes (Table 6).

\section{Discussion}

Chrysomya megacephala and Chrysomya rufifacies were the two calliphorides, which were found in all the seasons of the year. The duration of the life cycle depended on climacteric conditions and reflected yearly temperature changes. Corpses in summer and rainy season decayed as much faster rate than those in winter. Warmer temperature in summer speeded up succession while low temperature in winter retarded succession by slowing down the development rate of larvae.

Large numbers of studies have been done on effect of temperature on insect life cycle. P. sericata. P. regina, C. rufifacies and Cochliomyia macellaria development was slightly longer at fluctuating temperature than constant temperature [8-10]. The effect of controlled temperature and humidity on the life cycle, rate of development of thirteen species of flies, representing nine genera within the family Calliphoridae was also investigated [11-14].

Forensic entomology in the Indian perspective, finds insects to be important forensic indicator [15]. They study the relationship between insects and corpse decomposition. Singh and Bharti enlisted the species of blowflies order Diptera, family Calliphoridae Species $C$. megacephala, C. rufifacies, Calliphora vicina, L. sericata, and L. illustris available in the state of Punjab which can be important from the forensic point of view. It is also studied on entomological evidences covering all the five seasons of the year that is summer, rainy, autumn, winter and spring [16].

The present research is similar with the developmental duration of Chrysomya megacephala (Diptera: Calliphoridae), in rainy season and low constant temperature of $10^{\circ} \mathrm{C}$ and humidity $19 \%$, reported that the total life cycle duration in rainy season was completed in $265 \mathrm{~h} \pm 2 \mathrm{~h}$ (11.04 days \pm 0.08 days) when the temperature ranged between $26^{\circ} \mathrm{C}$ and $29^{\circ} \mathrm{C}$ and humidity ranged between $35 \%$ and $50 \%$, while in the low constant temperature $10^{\circ} \mathrm{C} \pm 0.5^{\circ} \mathrm{C}$ the life cycle was completed in 609 $\mathrm{h} \pm 4 \mathrm{~h}$ ( 25.38 days \pm 0.16 days $)$ indicating a delay in the life cycle by 14.37 days \pm 0.13 days [17]. Similarly our current results are in agreement with another study on the effect of different temperature and humidity on the life cycle duration and morphological parameters of Chrysomya rufifacies (Diptera: Calliphoridae) in different seasons, it was reported that the life cycle of Chrysomya rufifacies in summer was completed in $241 \pm 2.17 \mathrm{~h}(10.04$ days \pm 0.12 days $)$ when the temperature ranged between $30.1^{\circ} \mathrm{C}$ and $37.2^{\circ} \mathrm{C}$, but in the rainy season it was completed in $275 \mathrm{~h} \pm 2.27 \mathrm{~h}$ (11.46 days \pm 0.45 days), when the temperature ranged between $26.2^{\circ} \mathrm{C}$ and $30.1^{\circ} \mathrm{C}$, while in winter the life cycle was completed in $318 \mathrm{~h} \pm 2.45 \mathrm{~h}$ (13.25 days \pm 0.25 days) when the temperatures ranged between $26.4^{\circ} \mathrm{C}$ and $18.2^{\circ} \mathrm{C}$ respectively [18]. In present research work it is also observed that time duration of development of $\mathrm{I}^{\text {st }}$ instar larvae is lesser as compare to $\mathrm{II}^{\text {nd }}$ and III ${ }^{\text {rd }}$ instar larvae, it is similar with Nabity et al. [19] and Bharti et al. [20] recorded that $2^{\text {nd }}$ and $3^{\text {rd }}$ instars took prolong time for development as compared to $1^{\text {st }}$ instars; this may be due to different method of studies.

Insect development is dependent on environmental temperature, where the warmer temperature rate of development is faster [21,22].

\section{Conclusion}

From the present research work reported here, it is concluded that the duration of total life cycle of Chrysomya megacephala and Chrysomya rufifacies species are different in different seasons due to variation in temperature and humidity. Insect development is dependent on environmental temperature, where at the higher temperature, the development faster as compare to cooler temperature.

\section{Acknowledgement}

Authors are thankful to the Department of Zoology, Dr. Babasaheb Ambedkar Marathwada University, Aurangabad (MS), India for providing the laboratory facilities to carry out this research work.

\section{References}

1. Byrd JH, Castner JL (2009) Insect of forensic importance. In: Forensic entomology: The utility of arthropods in legal investigations (2nd Edn), CRC press, Boca Raton, Florida, USA pp: 39-126.

2. Rognes K (1991) Blowflies (Diptera, Calliphoridae) of Fennoscandia and Denmark, Fauna Entomologica Scandinavica, E. Brill, Leiden, pp: 272.

3. Ambrose DP (2007) The insect: Beneficial and harmful aspects (1st Edn) Kalyani publisher, Ludhiana, India, pp: 801.

4. Borror DJ, White RE (1970) A field guide to insect-America north of Mexico, Houghton Mifflin Company, Boston, USA.

5. Johnson MD (1975) Seasonal and microseral variation in the insect populations on carrion. J Amer Midland Natural 93: 79-90.

6. Putman RJ (1977) Dynamics of the blowfly, Calliphora erythrocephala within carrion. J Animal ecology 46: 853-866.

7. Khole V (1978) Studies on the population dynamics in larval blowflies (Diptera: Calliphoridae). Biovigyaram 4: 151-158.

8. Greenberg B (1991) Flies as a forensic indicator. J Med Entomol 28: 565-577.

9. Byrd JH, Allen JC (2001) The development of the black blow fly, Phormia regina (Meigen). Forensic Sci Int 120: 79-88.

10. Clarkson CA, Hobischak NR, Anderson GS (2004) A comparison of the development rate of Protophormia terraenovae (Robineau-Desvoidy) raised under constant and fluctuating temperature regimes. Can Soc Forensic 37: 95-101.

11. Mearns AG (1939) Larval infestation and putrefaction. Recent advances in forensic medicine. Smit KGV, Glaister J (Eds) Churchill P Blakiston's Co, Philadelphia, USA, pp: 250-256.

12. Singh D, Bharti M, Singh T (1999) Forensic Entomology in the Indian perspective. Journal of Punjab Academy of Science 1: 217-220.

13. Anderson GS, Laerhoven SLV (1996) Initial studies on insect succession on carrion in southwestern British Columbia. J Forensic Sci 41: 617-625.

14. Kamal AS (1958) Comparative study of thirteen species of Sarcosaprophagous, Calliphoridae and Sarcophagidae (Diptera) I. Bionomics. Ann Entomol Soc Am 51: 261-270.

15. Singh D, Bharti M (2001) Further observations on the Nocturnal Oviposition Behavior of Blow Flies (Diptera: Calliphoridae). Forensic Sci Int 120: 124-126.

16. Aggarwal AD (2005) Estimating the postmortem interval with the help entomological evidence. Thesis, Baba Farid Univercity of Health Science, Faridcote, Patiala, India. Anil Aggarawal's internet Journal of forensic Medicine and Toxicology 6: 2 . 
Citation: Siddiki S, Zambare SP (2017) Studies on Time Duration of Life Stages of Chrysomya megacephala and Chrysomya rufifacies (Diptera: Calliphoridae) during Different Seasons. J Forensic Res 8: 379. doi:10.4172/2157-7145.1000379

Page 5 of 5

17. Abd-AlGalil FM, Zambare SP (2015). Effect of temperature on development of Calliphorid fly of forensic importance Chrysomya megacephala (Fabricius, 1794). Indian J Appl Res 5: 767-769.

18. Abd-AlGalil FM, Zambare SP (2015a). Effect of temperature on development of Calliphorid flies of forensic importance, Chrysomya rufifacies (Macquart, 1842). IJAR: 1099-1103

19. Nabity, P. D., Higley, L. G. and Heng- Moss, T. M. (2006). Effect of Temperature on the Development of Phormia regina (Diptera:
Calliphoridae) and use of Development Data in determining Time Intervals in Forensic Entomology. J Med Entomol 43: 1276- 1286.

20. Bharti, M., Singh, D. and Sharma, Y. P. (2007). Effect of temperature on the development of forensically important blowfly, Chrysomya megacephala (Fabricius) (Diptera: Calliphoridae). Entomon 32: 149- 151.

21. Anderson G. S. Minimum and maximum development rates of some forensically important Calliphoridae (Diptera). J Forensic Sci 45: 824-832.

22. Brewer G (2001) Forensic Entomology. 